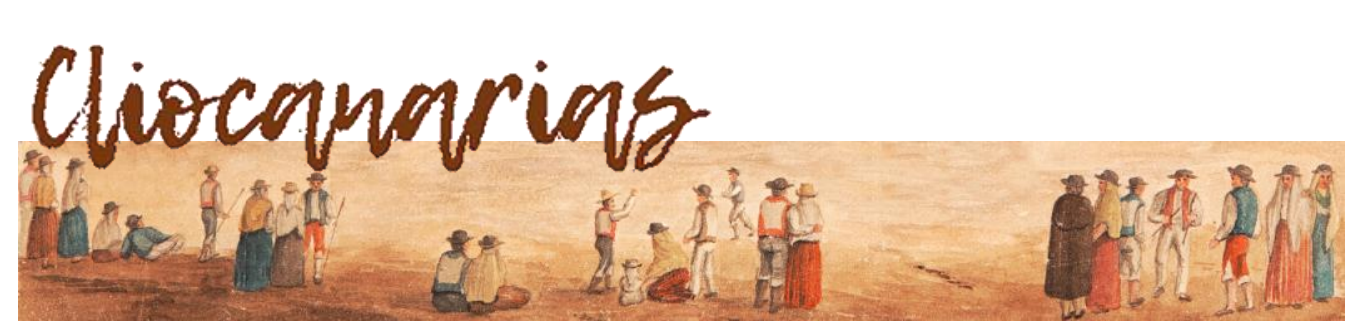

ISSN 2695-4494

https://doi.org/10.53335/cliocanarias.2021.3.08

\title{
MUNDIALIZACIÓN Y RELACIONES ECONÓMICAS, 1600-1850
}

WORLD-SYSTEM AND ECONOMIC RELATIONS, 1600-1850

Miguel Ángel ECHEVARRÍA BACIGALUPE*

RESUMEN: La temática de este trabajo se sustenta en las relaciones del poder político con las actividades económicas durante la primera mundialización. Los inicios de tal fenómeno tienen lugar a finales del siglo XVI, una vez consolidada la primera red mundial, y su término cuando llega a su madurez la Revolución Industrial inglesa y la colonización de las grandes áreas del planeta, en la primera mitad del siglo XIX. Así las cosas, nuestra aportación repasará las soluciones que las grandes potencias económicas del momento dieron a la dimensión espacial de sus actividades en el período referido.

PALABRAS CLAVE: mundialización, relaciones económicas, 1600-1850.

ABSTRACT: The theme of this paper is based on the relations of political power with economic activities during the first World-System. The beginning of such a phenomenon take place at the end of the Sixteenth Century, once the world's first network was consolidated, and its end, when the English Industrial Revolution and the colonization of the great areas of the planet reached maturity during the first half of the Nineteenth Century. Thus, our contribution will review the solutions that the great economic powers of the moment gave to the spatial dimension of their activities in the period referred to.

KEYWORDS: World-System, economic relations, 1600-1850.

\section{I}

Este trabajo se sustenta en el análisis de las relaciones entre el poder político y los agentes económicos durante la primera mundialización. Los inicios de tal fenómeno tienen lugar alrededor de 1600, con la primera red mundial consolidada, y su término cuando llegan a la madurez la primera revolución indus

\footnotetext{
* Profesor de Historia Económica (Universidad del País Vasco). C. e.: miguela.echevarria@ehu.eus
} 
trial inglesa y la ocupación de las grandes áreas del planeta, en las primeras décadas del siglo xx. Se trata de una temática nueva, porque ciertos acontecimientos actuales han hecho posible formular sobre ella diferentes puntos de vista aún no tenidos en cuenta.

Los coetáneos siempre se hallan confusos respecto de su propio tiempo; es el sino en todas las épocas, y la nuestra no podía ser una excepción. Hoy es la globalización quien nos perturba. La gente no sabe a ciencia cierta si es buena o mala, qué límites ha de tener, o qué actitudes ha de tomar nuestro Estado-nación ante el auge de los mercados sin fronteras aparentes. La actual crisis sanitaria que padecemos solo ha acentuado dicha tendencia, dividiendo a la opinión pública.

Pues bien, en los siglos modernos la situación fue un tanto similar, resumiéndose todo en los problemas generados por un nuevo desarrollo espacial antes no conocido. En vez de globalización como hoy en día, en que los espacios económicos traspasan diferentes áreas políticas a nivel planetario, había mundialización, o sea, dilatación espacial de ciertos poderes políticos por amplios territorios del mundo imponiendo los regímenes económicos y sociales más a su conveniencia ${ }^{1}$.

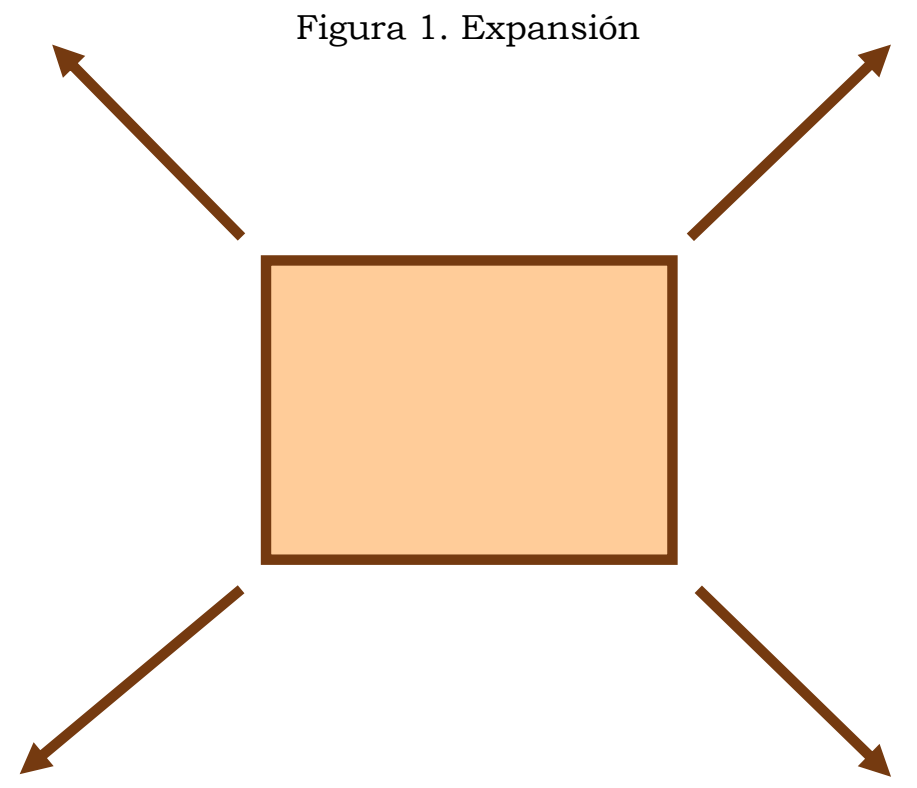

Pero la perplejidad y las dudas son las mismas para ellos y para nosotros. Toda expansión espacial supone un importante reto a la hora de encarar su gestión eficaz, entonces como ahora. El actual incremento de las posturas autárquicas y proteccionistas contrarias a la globalización nos pone de nuevo ante la vieja temática sobre la repetición de la historia. Evaluaremos en nuestra aportación qué hicieron las gentes de la modernidad ante el desafio, y de qué manera este afecta e interesa tanto a los estudiosos del pasado como a los especialistas actuales en politica económica. ¿Acaso se repite la historia mediante una propia e inexorable lógica que nos impide así aprender de lo pretérito para evitarlo? Así lo pareciera.

\footnotetext{
${ }^{1}$ Sobre esta cuestión, ECHEVARRÍA BACIGALUPE, Miguel Ángel: En los orígenes del espacio global. Una historia de la mundialización, Madrid, 2013, pp. 10-11.
} 


\section{II}

Para afrontar nuestra temática, quisiera decir algo que años atrás parecería obvio, pero que hoy es necesario resaltar. La tarea de gobierno de un soberano y sus ministros en los siglos modernos sí pasaba por el fomento de las actividades económicas; la doctrina es clara al respecto. La salud del rey dependía de la salud del reino, por el que aquel había de mirar; no en vano era normalmente el principal perceptor de rentas. Y dicha salud se concretaba en proteger el bienestar material de los gobernados, un bienestar que de rebote llenaba los reales cofres. De este modo, siquiera por motivos egoístas, el soberano estaba obligado a favorecer la agricultura, las artes mecánicas o el comercio, a la vez que miraba por la buena salud del sistema monetario, junto con el de pesas y medidas. Confiando las tareas a asesores y ministros, el rey practicará un tipo de politica económica en favor de las actividades materiales que desde ya hace mucho tiempo se ha venido denominando mercantilismo, o sistema mercantil.

Bueno será, antes que nada, definir qué entendemos por sistema mercantil. Desde nuestro punto de vista, es la suma de ideas y de prácticas económicas que muy especialmente en los primeros siglos modernos (siglos XVI y XVII) preconizan una fuerte intervención de los poderes públicos buscando generar un sistema coherente en términos espaciales, junto con el bienestar material de los gobernados. Mercantilismo, pues, como unión de espacios muy dispersos y heterogéneos, con el fin de vincularlos tanto en lo político como en lo económico. Mercantilismo, asimismo, como fomento de actividades productivas. $\mathrm{Pe}-$ ro mercantilismo también como privilegio del rey, como potestas regia. La "potestad regia" implica entre otras cosas una obligación; en este caso, el cuidado de los súbditos mediante la supervisión de sus actividades. Acompañando al resurgimiento del poder real, el sistema mercantil conocerá su afianzamiento durante el siglo XVI, con la expansión extraeuropea, hallando una auténtica edad de oro en los dificiles tiempos de la centuria siguiente. Ahora bien, ¿en qué se basa política y jurídicamente el poder real para controlar las actividades económicas de los súbditos en su propio bien? Contestaremos a ello haciendo un repaso de las teorias más representativas al respecto.

El rey es concebido como el padre y tutor (curator) de sus súbditos; estos, por su parte, están obligados a ayudar a su paternal señor. Cada súbdito es rey de su casa, un microcosmos del macrocosmos politico. La diferencia entre oikos y polis lo aclara: al particular le compete la oikos, esto es, lo privado; al príncipe, la polis, o sea, lo público ${ }^{2}$. La naturaleza nos aporta modelos perfectos: las hormigas son un ejemplo de economía (= gobierno de la casa), mientras que las abejas lo son del gobierno politico, comunitario (= reino) ${ }^{3}$. Micro y macro se combinan, pues, a la perfección.

¿Cómo se representaba la figura del rey en estos tiempos? Ciertamente de muy variadas maneras; aquí solo atenderemos a las principales. El monarca

\footnotetext{
2 Ibid., pp. 83-84.

3 TESAURO, Manuel: Filosofía Moral, derivada de la alta fuente del Grande Aristóteles Stagirita, Barcelona, 1715, p. 245. La similitud entre las abejas y el sistema de gobierno recorre toda la historia cultural de Occidente desde la Antigüedad; para el Antiguo Régimen: TAVOILLOT, François, y Pierre-Henri TAVOILLOT: El filósofo y la abeja, Madrid, 2017, pp. 132-141.
} 
era visto como jefe de una sociedad orgánica: cabeza o corazón, según fuera más conveniente la analogia ${ }^{4}$. También se le comparaba a una colmena ${ }^{5}$, o a un sistema planetario en donde la persona real quedaba normalmente asimilada al Sol, príncipe de los planetas por iluminarlos a todos, si bien ha de ceder su primacía a la Tierra, centro del universo según la creencia corriente ${ }^{6}$. El rey, asimismo, es representado como tejedor de urdimbres heterogéneas ${ }^{7}$, y también como músico en la Tierra, de la misma forma que Dios es el gran músico del cielo ${ }^{8}$. También es el médico que cuida del cuerpo de la república9. No podia faltar, por supuesto, la representación del sistema político como un cuerpo humano donde el rey es la cabeza; quizá sea esta la representación más popular de todas ${ }^{10}$. En cualquiera de estos casos, el soberano es representación viva de la armonía, fundamento de todo en política: en efecto, desde los tratadistas político-económicos hasta científicos como Johann Kepler ${ }^{11}$, hay una corriente perfectamente asentada a este respecto. En todo ello se ve desde luego la gran influencia del pensamiento político griego, en especial Platón y Aristóteles.

A partir de estas funciones metafóricas, los tratadistas enseñan en qué medida corresponde a la autoridad real ejercer unos poderes. Entrando, pues, en el terreno práctico, ¿cómo puede el rey controlar mejor sus posesiones y a sus vasallos? Mediante la burocracia (dentro de ella, el régimen de visitas ${ }^{12}$ ), el poder militar (Ejército/Marina), la religión (Iglesia, Inquisición) y la economía (implementando la primera política económica digna de ese nombre, a pesar de sus limitaciones e incoherencias). Absolutismo y mercantilismo van de la mano, pues existe una imperiosa necesidad del Estado moderno de unificar el espacio sometido a su jurisdicción ${ }^{13}$, contra actuales opiniones adversas y desprovistas de sentido común. El mercantilismo nos descubre luego el miedo de los modernos a la creciente volatilidad espacial que el desarrollo de las actividades económicas está imprimiendo desde finales del XV. Pero ojo: más

\footnotetext{
4 Cellorigo repite a menudo esa comparación. GONZÁLEZ DE CELLORIGO, Martín: Memorial de la política necesaria y útil de España, (J. L. Pérez de Ayala, Ed.), Madrid, 1991, pp. 95, 127, y $134-135$.

5 Ver nota 3.

6 CAMÓS, Marco Antonio de: Microcosmia y gobierno universal del hombre christiano para todos los estados y qualquiera dellos, Barcelona, 1592, parte II, p. 14. También, GONZÁLEZ DE CELLORIGO, Martín: Memorial de la política..., op. cit., p. 117. La problemática desde el punto de vista iconográfico, en MÍNGUEZ, Víctor: Los reyes solares. Iconografía astral de la Monarquía Hispánica, Castellón de la Plana, 2001.

7 ECHEVARRÍA BACIGALUPE, Miguel Ángel: Flandes y la Monarquía Hispánica, 1500-1713, Madrid, 1998, p. 74.

8 GONZÁLEZ DE CELLORIGO, Martín: Memorial de la politica..., op. cit, p. 128: El Príncipe, que es imagen de Dios, músico verdadero del instrumento de esta nuestra República.

9 Ibid., pp. 95 y 134-135.

10 TAVOILLOT, François, y Pierre-Henri TAVOILLOT: El filósofo..., op. cit., pp. 138-139.

11 Junto a los tratadistas, no estará de más aludir a un astrónomo célebre, Johannes Kepler, quien encuentra en el cielo la armonía de la Tierra, asimilando armonía y amistad (KEPLER, Johannes: Harmonices Mundi, Linz, 1619, p. 91).

${ }^{12}$ La "visita" aumentó el control regio sobre los territorios de soberanía. Para el régimen de la "visita", ÁLVAREZ DE TOLEDO, Cayetana: Juan de Palafox, obispo y virrey, Madrid, 2011, pp. 90-91.

${ }^{13}$ Es una tarea que no tuvo excepciones. Ver al respecto ZAUMAN, Zygmunt: La globalización, México, 2013, p. 41.
} 
que el "miedo a la mercancía", en famosa expresión de Heckscher ${ }^{14}$, juzgamos que se trata más bien de un miedo a la volatilidad de la mercancía, esto es, al desarrollo de una movilidad incontrolada que perjudique a los intereses económicos propios. La contabilidad será esa cadena de papel que ate un mundo jurisdiccional disperso espacialmente ${ }^{15}$. El rey será básicamente absolutista/intervencionista en el terreno económico ${ }^{16}$, cosa que no podía ser tanto en el político-judicial. Imposible hablar de dirigismo económico como lo hacemos hoy, porque los conceptos son muy distintos. Actualmente vivimos aún en un régimen abierto, mecanicista, donde las partes y sus atribuciones y funciones están separadas legalmente. Por aquel entonces, el régimen era orgánico, y en él los límites entre lo público y lo privado eran más difusos por formar parte de un todo. Si el rey no dirige las actividades privadas, posee sin embargo una auténtica jurisdicción territorial exclusiva sobre cuestiones clave como la del comercio exterior. Y ello, porque defiende su territorio (económicamente, esta vez) contra los enemigos; de ahí le viene precisamente el poder jurisdiccional. Sin renunciar, por supuesto, a la vía militar como alternativa en caso de insuficiencia, porque la guerra es esencial para el gobierno de la república, como oportunamente comentara Alonso de Ercilla en su obra La Araucana (canto XXXVII):

\section{La guerra es de derecho de las gentes, $Y$ el orden militar $y$ disciplina Conserva la república y sostiene, $Y$ las leyes politicas mantiene ${ }^{17}$.}

Pero con todo, este poder regio tiene sus limitaciones, como los súbditos le harán ver. Primero, la legislación local en terreno de intercambios y fueros particulares; en esto, las provincias vascas son un claro ejemplo con los tratados de conversa, o de buena correspondencia, que abrian de hecho la frontera hispanofrancesa por aquel territorio ${ }^{18}$. Luego, se le hace saber por parte de los gobernados que la necesidad no tiene ley, y que la ley positiva puede transgredirse en determinadas circunstancias; de ahí deriva en ocasiones la defensa del contrabando en beneficio de los particulares. Esto se explica, en

\footnotetext{
${ }^{14}$ HECKSCHER, Eli F.: La época mercantilista, México, 1983, p. 561.

15 El papel central de la contabilidad, en HERNÁNDEZ ESTEVE, Esteban: Establecimiento de la partida doble en las cuentas centrales de la Real Hacienda de Castilla (1592), Madrid, 1986. Asimismo, DONOSO CORTÉS, Rafael: Una contribución a la Historia de la Contabilidad. Análisis de las prácticas contables desarrolladas por la Tesorería de la Casa de Contratación de las Indias de Sevilla (1503-1717), Sevilla, 1996.

${ }^{16}$ ¿Podriamos hablar de dirigismo en el Antiguo Régimen? El dirigismo fue más bien a nivel local y entre los particulares (gremios, por ej.). El poder concede privilegios (octrois), pero su gestión es particular. Incluso si toma la gestión de determinada empresa, es con la idea de entregársela a los particulares previamente saneada. Solo las grandes directrices en politica económica le pertenecen.

${ }_{17}$ No deja de ser chocante que la guerra contra los indios mapuches en el sur del actual Chile, a que se refiere Ercilla, fuera la única inconclusa que dejó la monarquía tras cerca de trescientos años de dominación en el continente americano.

18 Una sintesis de esta problemática, en LUGAT, Caroline: "Les traités de Bonne Correspondance: une dérogation aux règles du droit maritime international?", Itsas memoria, 5 (2006), pp. 301-308. Eso dificultó grandemente la represión del contrabando, pero no la anuló; ver al respecto: TRUCHUELO GARCÍA, Susana: "La represión del fraude comercial en el litoral vasco en el período altomoderno", Boletín Sancho el Sabio, 23 (2005), especialmente pp. 13-15.
} 
parte, porque la Corona había entregado en arriendo la recaudación de las aduanas a los particulares a cambio de un tanto alzado. Además estaba la cuestión de las monedas, un constante tira y afloja entre el monarca y los poderes locales por el monopolio de emisión, como se ve claramente, por ejemplo, en Flandes ${ }^{19}$. ¿Se puede llevar a cabo una política proteccionista coherente entregando las aduanas a los particulares y sin control efectivo de la fabricación de numerario? Aparentemente, no; pero tengamos en cuenta que por aquel entonces las atribuciones del Estado eran más bien de carácter indirecto. Luego, se tiende más bien a regular el tráfico vía aranceles, ganando de paso con la percepción de una renta anual beneficiosa para el poder politico. Solo se prohíbe o controla fuertemente el comercio de productos estratégicos, como los metales preciosos; en cuestión de moneda, la preponderancia ecuménica de especies como el real de plata constituye un auténtico imperialismo monetario sobre los territorios propios y a nivel internacional, lo que procura beneficios al sector financiero, si bien a costa del exportador y comerciante en general ${ }^{20}$. Además de este caso, suele darse en tiempo de economía de guerra o de guerra económica ${ }^{21}$, y se trataría de amedrentar a terceros vía represalias con vistas a un posterior acuerdo.

Según lo contemplado, era inevitable la confrontación entre poder público e intereses privados, derivada de la imprecisión de roles a que aludiamos. Ese choque era percibido claramente por los coetáneos, especialmente en aquellas áreas de predominio capitalista, como los Países Bajos. Por eso escribió Justo Lipsio que lo particular siempre es incomodado por lo público, validando en su doctrina conceptos como libertad e iniciativa personal, principios estos que se repetirán después en algunos escritores holandeses ${ }^{22}$. La oposición al control estricto y las prohibiciones de relacionarse con socios potenciales o efectivos se tradujeron en continuas protestas ante el poder, pero asimismo en la elaboración de marcos teóricos sobre las ventajas del commercium universal como generador y garante de paz y riqueza. De entre todos destacaremos al parmesano Alberto Struzzi, comerciante y hombre de negocios que viviera muchos años en Flandes, lo que lo mantuvo muy al corriente sobre las necesidades de una clase capitalista ávida de espacios donde traficar, o a los que subvencionar. Es sin duda este memorialista uno de los que por aquel entonces mejor comprendió las dimensiones globales del comercio y las finanzas y, por consiguiente, la exigencia de aligerar el control en política económica para beneficiarse de un mundo cada vez más al alcance de la mano ${ }^{23}$. Su aporte, aunque señero, se enlaza con un ambiente de reflexión sobre la importancia

19 LEGAY, Marie-Laure: La souveraineté monétaire dans les Pays-Bas méridionaux, XVIe-XIXe siècle, Turnhout, 2016, pp. 105-106.

${ }^{20}$ Devaluar la moneda viene bien a los comerciantes; revaluarla, al Estado y a los financieros. No se olvide esto, porque explica la actitud del gobierno español en esta época.

21 "Economía de guerra" es la disposición estructural de una economía de cara a las necesidades bélicas. "Guerra económica" consiste en usar medios represivos de naturaleza económica para lograr la victoria sobre el enemigo (embargos, bloqueos, destrucción de fuentes de riqueza...).

22 SECRETAN, Catherine: Le 'Marchand Philosophe' de Caspar Barlaeus. Un éloge du commerce dans la Hollande du Siècle d'Or, Paris, 2002, p. 98.

${ }^{23}$ ECHEVARRÍA BACIGALUPE, Miguel Ángel: Alberto Struzzi, un precursor barroco del capitalismo liberal, Leuven, 1995, passim. 
de lo privado, que llevará a defender en los Países Bajos una vasta autonomía de pensamiento: se buscan certezas por encima de las opiniones y, sobre todo, de las determinaciones económicas del poder, o sea, la famosa política económica. Los intereses del individuo y del gremio por encima o enfrente de los del Estado, tal es la conclusión que se abre, llegado el siglo XVII, en los Países Bajos $^{24}$. El poder público, inquieto, sofocará en lo posible tales aspiraciones. Si entre los comerciantes y el Estado existieron querellas, las habrá mayores aún con los financieros, cuya movilidad espacial es más acusada. Además de los problemas arriba señalados, hubo contradicción entre el área política, esencialmente perimetral o de fronteras (= estática), y la economía dinámica de carácter reticular disperso a falta de un auténtico mercado interior, inexistente o muy imperfecto por el momento, y porque todo depende asimismo de la lógica económica, no siempre de acuerdo con la lógica política. Ganan los financieros por las necesidades del Estado, ya que la revaluación monetaria atrae capitales a la inversión. Pero no les sale gratis: control de cambios y aplazamiento en el pago de principal e intereses fueron la cruz del gremio financiero en esta época.

En todos los casos, la Corona y el sector privado trataron de alcanzar un entendimiento que redundase en beneficio mutuo. Pero eso no quiere decir, como a veces suele afirmarse, que los particulares estuvieran respaldando al poder politico en todas sus decisiones, que existiera tácita connivencia entre ambos, o bien hablar de dirigismo estatal como se entiende hoy. Cuando hay contradicciones insalvables, las posturas de cada parte se hacen saber y se pretenden imponer al otro. Hubo más choques entre el poder y los intereses particulares de los que suele pensarse para la época absolutista. La situación era especialmente grave si el área politica se veía sometida a unas relaciones exteriores deficitarias en economía, como fue el caso de España. Sin embargo, la obsesión supervisora fue universal, bien para evitar o limitar el déficit, bien para conseguir o incrementar el superávit de la balanza.

Al mercantilismo fiscalizador se opone el aperturismo de los medios capitalistas, especialmente los financieros, representados en el continente europeo por la banca (italiana, flamenca, de Europa central), apoyada por las grandes casas comerciales. Los demás han de acomodarse y sacar ventajas del poder político, mientras tienden redes entre ellos y practican el contrabando de manera más o menos disimulada. Era algo inevitable si aceptamos que la esencia del comercio y las finanzas es la elasticidad espacial en forma de red crecientemente densificada, mientras que la lógica política concebía las áreas de forma perimetral acumulativa. Y luego está el problema del dinero, pues al ser de uso universal en estos siglos, en él convergen los intereses particulares y los generales. Eso genera una aguda lucha de competencias entre el monarca y las entidades locales con permiso de acuñación, salvo en el reino de Castilla, cosa que traerá sus derivaciones importantes sobre la politica monetaria regia, y por ende, sobre su política económica.

${ }^{24}$ ECHEVARRÍA BACIGALUPE, Miguel Ángel: "Arbitrismo y política económica, siglos XVI y XVII", en RIBOT GARCÍA, L. A., y L. de ROSA (eds.): Pensamiento y Politica Económica en la Época Moderna, Madrid, 2000, p. 17. 


\section{III}

El hondo significado del mercantilismo en la politica y la economía de aquellos tiempos preindustriales está, pues, en la espacialidad, por el carácter discontinuo y extenso de los espacios a controlar ${ }^{25}$. El mercantilismo era el mal menor para frenar la excesiva dispersión espacial. Este problema no es secundario, sino central en el desenvolvimiento exterior de las potencias occidentales europeas. De hecho, había sido causa fundamental de la declinación de imperios y monarquías, según la opinión de la época. Por eso, y centrándonos ahora en la monarquía hispana, los monarcas ideales eran ahí los Reyes Católicos ${ }^{26}$, ya que gobernaron un espacio coherente y no disperso, como los Austrias $^{27}$. Trajano extendió el espacio imperial, y de ahí vinieron los males de los romanos; así le está pasando a la España de los Habsburgo. Martín González de Cellorigo disimula escribiendo que la prudencia de los reyes Felipe II y Felipe III ha mitigado los inconvenientes de la espacialidad dilatada, aunque admite, muy a su pesar, que ya se están dando claros síntomas de decadencia $^{28}$. El italiano Botero remacha la cuestión diciendo que lo ideal es ser potencia terrestre, no marítima, y que la metrópoli debe tener colonias cercanas a sí29. En conclusión, los coetáneos se preguntaban: ¿habria, pues, que deshacerse de espacios exteriores? En caso afirmativo, ¿cuáles? Cada uno opinará según su criterio, como era de esperar.

El desafio de entender la elasticidad espacial en la monarquía hispana derivará en tres opciones. Unos la conciben como fábrica y otros como máquina, aunque siempre con el mismo sentido, esto es, algo trabado a partir de pedazos, de partes distintas y sueltas ${ }^{30}$. El concepto de organismo está igualmente muy asentado, e implica una trabazón más completa, por cuanto que las partes son inseparables, aunque desde luego forzosamente solidarias. Los escritores de la época soslayan hábilmente una cierta contradicción entre esas ideas porque son panegiristas de las glorias del conjunto hispano, pero la discordancia no dejará de estar presente en algún caso, como el de Saavedra Fajardo ${ }^{31}$. Las Indias, ¿'son parte del cuerpo místico, de la fábrica, o bien de la máquina? La asimilación del Nuevo Mundo al área política de la monarquía muestra claramente las intenciones del poder central. ¿Y qué pasa con el problemático Flandes: forma parte o no de la monarquía? Las discusiones sobre el particular van a agudizarse alrededor de 1600, pero no cesarán hasta nuestro abandono de aquellas tierras, iniciado el s. XVIII ${ }^{32}$.

\footnotetext{
25 ECHEVARRÍA BACIGALUPE, Miguel Ángel, En los orígenes..., op. cit., pp. 106-107.

26 GONZÁLEZ DE CELLORIGO, Martín: Memorial de la politica..., op. cit., pp. 94-95, y GIL PUJOL, Xavier, La fábrica de la monarquía, Madrid, 2016, p. 53.

27 GONZÁLEZ DE CELLORIGO, Martín: Memorial de la politica..., op. cit., pp. 95-96.

28 Ibid., p. 94.

${ }^{29}$ BOTERO, Giovanni: Diez Libros de la Razón de Estado, Madrid, 1593, pp. 10-11, y del mismo autor: Los tres libros de la magnificencia de las ciudades, Madrid, 1593, p. 205. Asimismo, DESCENDRE, Romain: L'état du monde. Giovanni Botero entre raison d'Etat et géopolitique, Genève, 2009, p. 235.

30 GIL PUJOL, Xavier: La fábrica..., op. cit., p. 35.

31 Ibid., p. 52.

32 De todas las posesiones, los Países Bajos serán quienes causen más quebraderos de cabeza a los gobernantes y a sus asesores. No todos vieron con agrado su inclusión en el seno de la
} 
La cuestión flamenca, por su importancia, tuvo inevitablemente una atención especial; aquí nos ocuparemos especialmente de la vertiente económica. En Flandes había gremios y cofradias más o menos similares a las instituciones ibéricas, pero asimismo hubo amplia libertad en el comercio, hasta el punto de que el mercado interior estaba razonablemente articulado, y se copaban determinadas áreas del mercado exterior, preferentemente hispánico, junto con mercados vecinos ${ }^{33}$.

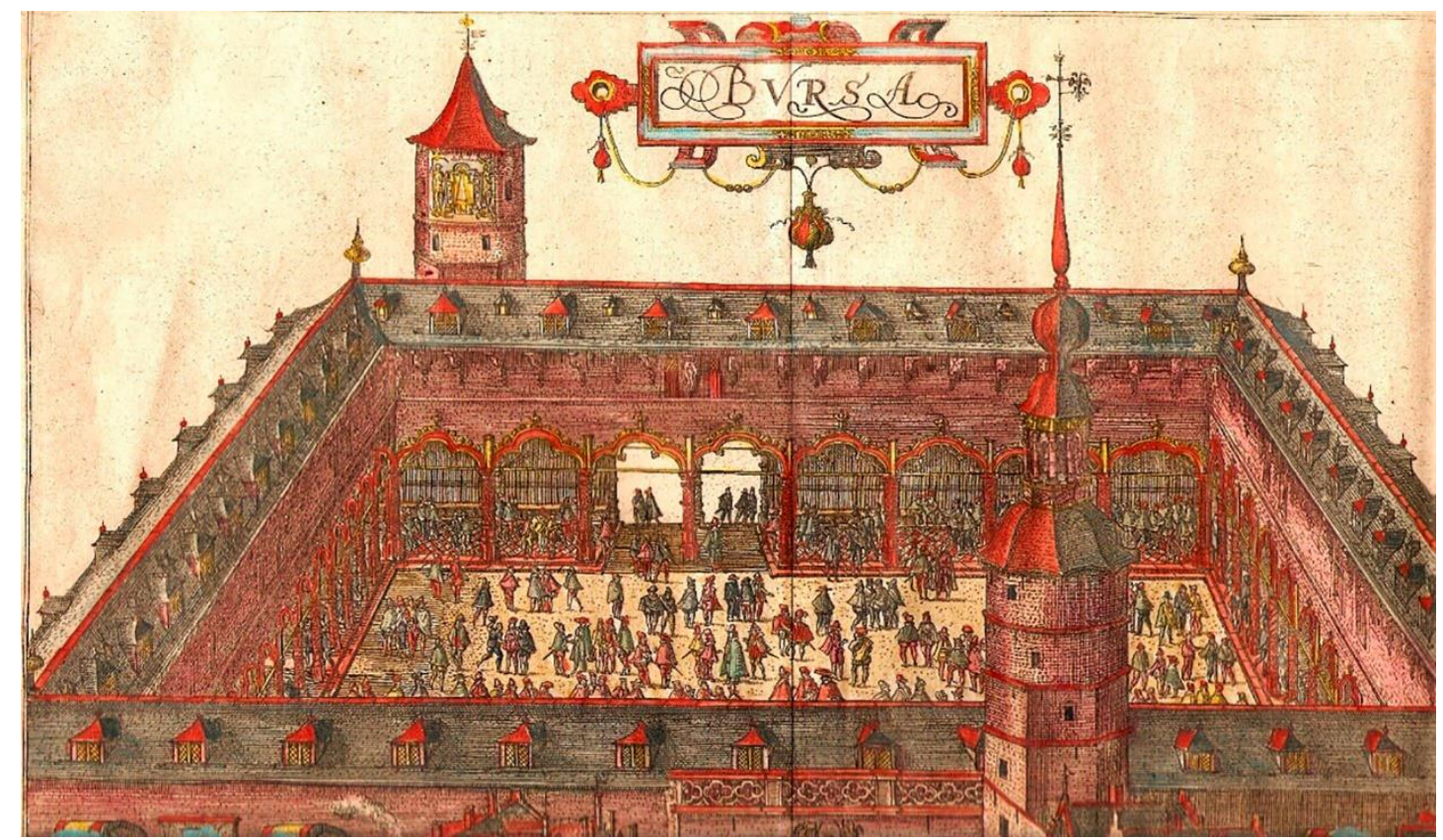

Imagen: Bolsa de Amberes hacia 1560 [Grabado siglo XVI]. La ciudad del Escalda se convirtió, andando el quinientos, en un centro clave para la naciente economíamundo. (Colección del autor)

¿Qué pasó cuando Felipe II y sus sucesores apretaron las tuercas a los comerciantes y financieros? Pues que la volatilidad espacial, tan característica del sector servicios, iba a provocar protestas; incluso generó doctrinas económicas de sesgo antimercantilista, como la del ya mencionado Alberto Struzzi, autor de propuestas de liberalización de relaciones entre mercados que sorprenden por su radicalidad y que, como cabía esperar, no fueron atendidas ${ }^{34}$. El asentamiento del poder español en Flandes solo traerá consigo intervencionismo militar, manejos en los gobiernos locales, o influencia en algo tan vital como la acuñación de moneda (contra las pretensiones de un sector de opinión más partidario de una amplia autonomia, postura de facto insostenible, precisamente por la misma dispersión espacial), más un pensamiento fiscal claramente intervencionista por parte del sector público. La pugna en el régimen español y el flamenco se hizo visible entre un archiduque Alberto, de voluntad absolutista, y un Felipe III no menos celoso de fiscalizar el poder. Porque en

monarquía. Sobre el caso, ECHEVARRÍA BACIGALUPE, Miguel Ángel: Flandes..., op. cit., pp. 120-126.

33 Ibid., p. 242.

${ }^{34}$ Struzzi llegó a proponer en 1625 un sistema aduanero flexible y en equilibrio entre la demanda y oferta internas de cada bien o servicio, que en cierto modo recuerda las leyes del grano inglesas (Biblioteca Nacional de Madrid, ms. 10.441, f. ${ }^{\circ} 3$ ). Como decimos, no fue escuchado, lo que exacerbó su postura hacia un mayor librecambismo. 
el bando hispano, el control forma parte de la reputación, y el descontrol, de la deshonra; esto es, hay que intervenir, aun consintiendo cierta autonomia. La vuelta al mando directo de Madrid después de 1621 solo cambió parcialmente las cosas. Cuando la extenuante guerra apriete las tuercas del tesoro público, este hará una llamada a las provincias de los países obedientes, que a cambio de mayores aportaciones y de soportar unos "costes alternativos no reproductivos" crecientes, lograrán, petición tras petición, un mayor manejo de los asuntos propios 35 .

Pero más allá de discusiones y teorias, hay que destacar la búsqueda de soluciones prácticas a tanta dispersión. Una es la de crear un espacio económico común, seguida años después por el intento de formar una Unión de Armas para la defensa de la monarquía. Destacaremos aquí solamente lo relativo a la unidad económica, que se sustancia en el llamado "decreto Gauna", del año 1603. Juan de Gauna, un guipuzcoano residente muchos años en Flandes, propuso a Felipe III en 1601 crear una especie de mercado interior hispánico donde los vasallos naturales del rey comerciarian libremente entre sí, pero en lo que concierne a exportaciones e importaciones, pagarian, además de los derechos arancelarios usuales, un derecho extra del $30 \%$ ad valorem sobre cualquier mercancía que el poder politico designara como estratégica. Ese 30 \% se recobraría demostrando que el producto no viajará a países enemigos ni entró desde ellos en territorio regio; de lo contrario, se le mantendría el fuerte recargo, con lo que dicho producto saldría mucho más caro. El proyecto se convirtió en decreto el 27 de febrero de $1603^{36}$. Las ideas clave de esta peculiar iniciativa son dos: primero, acostumbrar a los vasallos reales a comerciar y relacionarse entre sí, al poder recobrar el derecho del 30 \%; segundo, expulsar del mercado interno de la monarquía a los enemigos y los falsos amigos. De ambos fines emana un claro propósito, recogido en el real decreto de 1603, y no es otro que el de crear una unión económica entre todos los territorios de la casa de Austria hispana, idea perfectamente mercantilista que el tiempo demostrará quedar notablemente anclada en la politica comercial exterior de España. La mundialización había dado un gran paso al crear un sistema aduanero de carácter global con vistas a formar un bloque económico homogéneo, una especie de "mercado común hispánico»37. A destacar

\footnotetext{
35 Llamamos "costes alternativos no reproductivos" a esa serie de gastos derivados de la destrucción de capital derivada del conflicto bélico, y que caían sobre las espaldas del pueblo e instituciones de los Países Bajos meridionales, por cierto con cada vez más intensidad. Para el grado de autonomía financiera flamenca en el régimen español: ECHEVARRÍA BACIGALUPE, Miguel Ángel: "La Hacienda en Flandes y la hegemonía española, 1500-1621", en RIBOT, L. A. (dir.): Las finanzas estatales en España e Italia en la época moderna, Madrid, 2009, pp. 177-180.

36 El plan de Gauna, en ECHEVARRÍA BACIGALUPE, Miguel Ángel "Un notable episodio en la guerra económica hispano-holandesa: el Decreto Gauna (1603)", Hispania, 162 (1986), pp. 57-97.

37 Nótese que, en principio, las barreras aduaneras interiores de la monarquía quedaron incambiadas. Por eso no se puede equiparar de manera estricta el Decreto Gauna al Zollverein alemán o al Mercado Común Europeo.
} 
que este precedente será repetido en siglos posteriores por diversas naciones poseedoras de espacios dispersos y heterogéneos ${ }^{38}$.

Es de notar igualmente que la política económica de Gauna se inscribe dentro del programa del "partido español" en Flandes, de honda influencia en la Corte de Madrid y que estaba representado por un amplio número de gentes provenientes del País Vasco, quienes deseaban reservar el inmenso potencial humano y de recursos de la monarquía a los súbditos reales en exclusiva ${ }^{39}$. Ahora bien, el origen cantábrico de los defensores de esta opción chocará con la visión castellanista de la monarquía, la cual, acusando al grupo vascongado de mirar solo por sus propios intereses, pedirá para sí con insistencia el control exclusivo de la política económica hispana ${ }^{40}$.

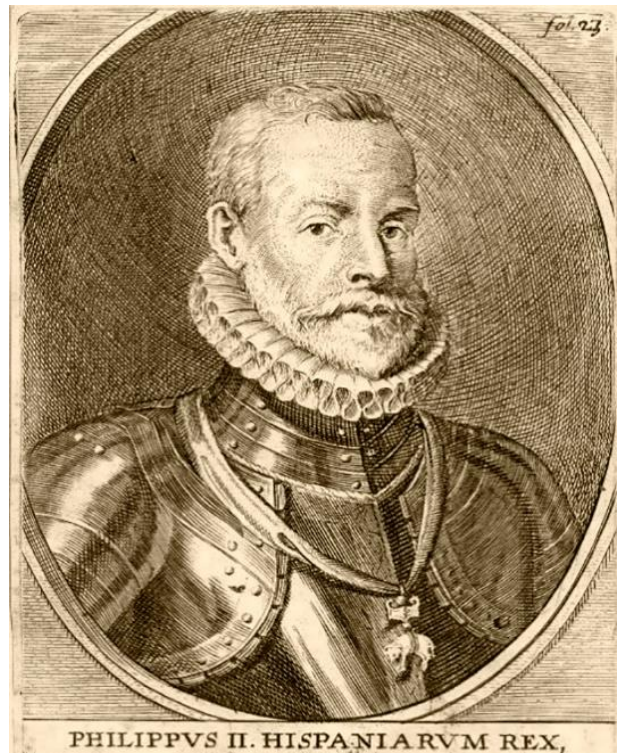

Imagen: Felipe II [Grabado, siglo XVIII]. Fue el primer monarca que hubo de hacer frente a las necesidades y problemas de una politica económica realmente mundial. (Colección del autor)

La referida problemática se complicó al estar relacionada con la acometividad de potencias europeas contra la expansión de la monarquía católica. Se pasa entonces a una dinámica de amplio carácter territorial, fruto de la expansión iniciada con Carlos V y multiplicada bajo Felipe II. Fue este último soberano quien imprimirá al sistema mercantil un escenario europeo, y aun mundial.

Desde fines del s. XVI, los enemigos neerlandeses e ingleses se muestran cada vez más y más osados, trasladando la lucha lejos de sus limites territoriales. A los ataques ingleses a Cádiz de 1587, y especialmente el anglo-holandés de $1596^{41}$, hay que sumar la brutal acometida de los neerlandeses a las islas Canarias en 1599, prólogo de la feroz guerra colonialista de carácter planetario que dominará el siglo XVII. El archipiélago, núcleo esencial en la ruta europea hacia América y África (con vistas a Asia) ${ }^{42}$, fue visitado con cada vez mayor insistencia por los rebeldes holandeses, en ocasiones con una finalidad bélica, pero muchas otras veces para abastecer al territorio insular de bienes y servicios ${ }^{43}$. Los holandeses llegaron a formar con el tiempo diver-

\footnotetext{
38 Por ejemplo, es llamativo que los británicos crearan un sistema bastante parecido en 1932 para responder a las dificultades creadas por la crisis de 1929; se trata de la "Preferencia Imperial".

39 ECHEVARRÍA BACIGALUPE, Miguel Ángel Flandes..., op. cit., pp. 166-167.

40 ECHEVARRÍA BACIGALUPE, Miguel Ángel: En los orígenes..., op. cit., p. 203.

${ }^{41}$ Una buena perspectiva del acontecimiento, en BUSTOS, M. (dir.): El asalto anglo-holandés a Cádiz en 1596 y su contexto internacional, Cádiz, 1997, passim.

42 SANTANA PÉREZ, Germán: «Encuentros y transformaciones en la construcción histórica de las Antillas y las Islas Canarias. Siglos XV-XVII", Anuario de Estudios Atlánticos, 53 (2007), p. 75.

43 Una visión genérica, en SANTANA PÉREZ, Germán "Canarias: base de la actuación holandesa en el Atlántico (siglos XVII y XVIII)", Cuadernos de Historia Moderna, 29 (2004), en especial pp. 93-96.
} 
sas rutas de largo alcance; una de las primeras iba de Holanda a la isla francesa de Ouessant, luego a Gran Canaria, de ahí al Caribe (Santo Domingo, Tierra Firme), Terranova y vuelta a Holanda, un circuito altamente productivo, desde luego ${ }^{44}$, que después se iría sofisticando hacia una mayor mundialización. El influjo comercial holandés marcará con fuerza el espacio económico afectado por aquel.

Concluyendo este caso, los problemas para España estarán lejos de terminar, antes bien crecerán exponencialmente con las ambiciones de enemigos y neutrales, como el futuro demostrará. Por eso, el mercantilismo peninsular quedará cada vez más ligado a la guerra, aunque en una doble vertiente, la militar y la económica. Un esfuerzo agotador que repercutirá en la salud del conglomerado hispánico, cuya extensión planetaria multiplicó los problemas de mantenimiento, encareciéndoles. Y precisamente por eso, el centro político careció de los recursos necesarios para su propia subsistencia y mejora.

En la Europa de entonces hubo otros modelos espaciales más o menos similares. Uno a destacar es el efectuado a lo largo y ancho del Sacro Romano Imperio. Hay diferencias muy claras entre el mercantilismo y el cameralismo, politica económica pensada para un territorio compacto y estable (frente al expansionismo de las potencias occidentales), que en este caso se llevó a cabo desde la capital política. El llamado Sacro Romano Imperio era un espacio geográfico centrado en la cuenca danubiana, la cual se desarrolla - como es sabido- entre Alemania y el Mar Negro, alargando su influencia entre el Báltico y el Mediterráneo. Esto permitió extender una red eficiente de comunicaciones desde Viena, corazón del sistema, lo que abarcó desde los aspectos militares a los económicos, políticos o ideológicos ${ }^{45}$, haciendo posible un sistema como el cameralismo, centrado más bien en los aspectos administrativos y fiscales que en los mecanismos para la obtención de riqueza, aunque estos no fueran dejados completamente de lado. No obstante, si ganaba en cohesión territorial, el cameralismo tenía su propio talón de Aquiles: las peculiaridades político-jurídicas de las diferentes partes del Imperio no permitieron una politica económica de suficiente coherencia, justamente al contrario de lo que hacían Francia o Inglaterra ${ }^{46}$. Aunque de menor entidad, es el mismo mal de la dispersión señalado por los tratadistas hispanos del Siglo de Oro.

Las Provincias Unidas son el único ejemplo en Europa de dominio capitalista sobre el sistema mercantil, de por sí esencialmente politico: liberadas de un poder superior tras la separación del monarca español ${ }^{47}$, las siete provincias formarán un aglomerado de espacios interiores que se dirigen hacia el mercado externo en busca de beneficios, o cuanto menos en evitación de mayores perjuicios. La división provincial no obstó a la unidad de mercado ni en

\footnotetext{
${ }_{44}$ Archivo General de Simancas, Secretaria de Estado, leg. 617, s. f. Archiduque Alberto a Felipe III, 30 de noviembre de 1600.

45 WESS MITCHELL, A.: The Grand Strategy of the Habsburg Empire, Princeton, 2018, p. 28.

${ }^{46}$ Este modelo germánico, en HECKSCHER, Eli F.: La época..., op. cit., pp. 41-62. Asimismo, BLAICH Fritz: Die Epoche des Merkantilismus, Wiesbaden, 1973, pp. 154-178.

$47 \mathrm{Su}$ dependencia respecto del Sacro Romano Imperio no obstaculizó una gran libertad de acción, que lograrían por completo tras el Tratado de Westfalia.
} 
las Provincias Unidas, ni lo hizo en los Países Bajos meridionales ${ }^{48}$. El mercado cohesionado es en sí mismo consecuencia de una decisión de orden político, no económico, porque afecta a un área en sí típicamente perimetral como es la política. En aquellos siglos había mercados entrelazados pertenecientes a entidades politicas distintas, pero solo mientras se mantuviera la complementariedad. Claro está que el fomento del mercado externo era la opción más segura; no era bueno enfadarse con el poder cuestionando sus principios e intereses. El contrabando con el enemigo era otra opción, aunque irregular, por hallarse sometida a inconvenientes; el comercio regular a base de precios sin competencia era la opción más realista y segura. Estado y comercio vienen a ser la misma cosa en las Provincias Unidas, especialmente considerando la existencia de grandes compañias como la VOC (Compañía de Indias Orientales) y la WIC (Compañia de Indias Occidentales), entes privados a los que se confia (como en el caso inglés) la colonización y explotación de los territorios ${ }^{49}$.

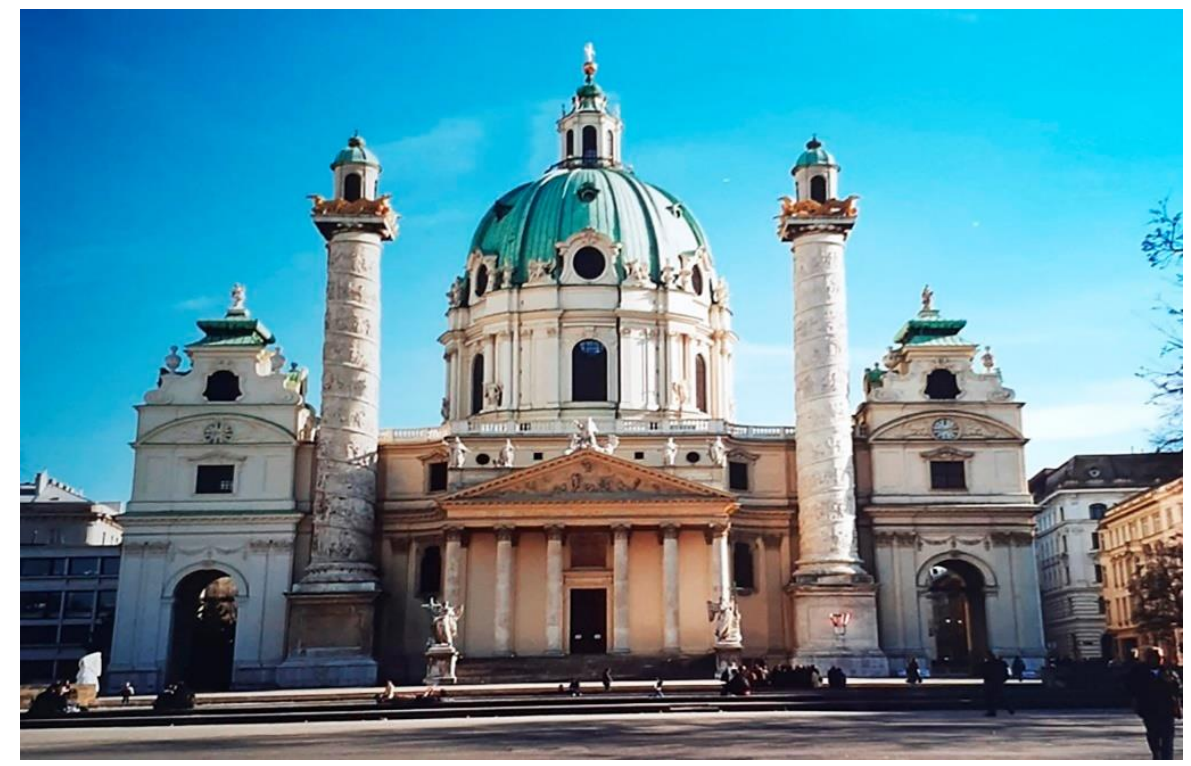

Imagen: Iglesia de S. Carlos (Viena) (Foto del autor)

Desestiman la pauta estatalista de los ibéricos (especialmente España), por lo que no desean conquistar espacios, sino pactar con poderes locales fuertes y asentarse en lugares clave; renuncian, pues, a acumular territorios anexos a la "madre patria" como hicieran los españoles (las posesiones extraeuropeas forman parte integrante de la monarquía, y la politica económica vale tanto para Castilla como para el resto). De ello emana el peculiar mercantilismo holandés o, por mejor decir, la ausencia de una politica mercantilista estatal propiamente dicha (en realidad, podria llamarse "mercantilismo privado" frente al

48 T HART, Marjolein: «Freedom and restrictions. State and economy in the Dutch Republic, 1570-1670", en DAVIDS, K. y L. NOODEGRAAF (eds.): The Dutch Economy in the Golden Age, Amsterdam, 1993, pp. 105-130. Igualmente, DE VRIES, Jan, y Ad VAN DER WOUDE: The First Modern economy. Success, failure, and perseverance of the Dutch Economy, 1500-1815, Cambridge, 1997, pp. 159-165.

${ }^{49}$ Para el caso, se puede seguir consultando con fruto el clásico de BOXER, C. R.: The Dutch Seaborne Empire, 1600-1800, London, 1990, especialmente capítulos 6 y 7. Asimismo, KLOOSTER, Wim: The Dutch moment. War, Trade, and settlement in the Seventeenth-Century Atlantic World, Ithaca, 2016. 


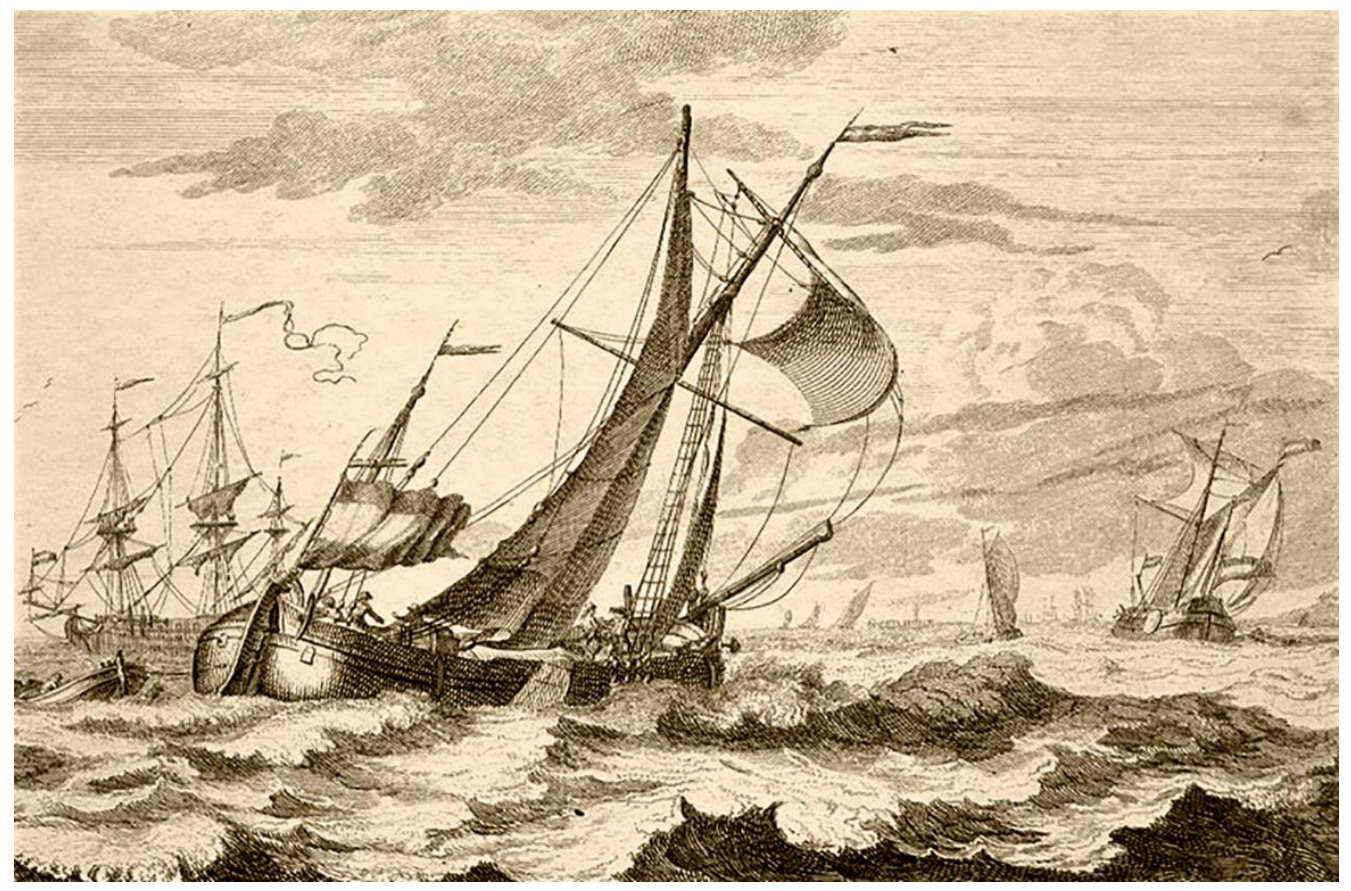

Imagen: Poder maritimo holandés [Grabado del siglo XVIII]. Tanto por su poderosa flota pesquera como por su imponente flota de alta mar, las Provincias Unidas dominaron la economía-mundo en buena parte del siglo XVII. (Colección del autor)

"mercantilismo público" de los Estados). En las provincias del norte, el mare clausum iba a dejar paso inevitablemente al mare liberum. Hugo Grocio tuvo gran influjo; otros pensadores económicos neerlandeses como De la Court o Graswinckel también, pero en menor medida ${ }^{50}$. Dicho sea de paso, la agresividad comercial de los ingleses será paralela a la holandesa, y se traducirá en la supremacía mercantil global a expensas de terceras potencias. Eso sí, sus fundamentos teórico-prácticos recuerdan los casos español y francés.

Siguiendo con el tema, si reclaman mare liberum, ¿son mercantilistas las Provincias Unidas? Dificilmente, al menos hasta ocupar una posición de hegemonía comercial. Libertad para navegar, pero no para gestionar el negocio mercantil, en manos de compañias. Los métodos de gestión serán mercantilistas, aunque no por parte del Estado (que no existe como tal en un sentido corriente del término), sino de la oligarquía comercial, que además gobierna la ciudad o la provincia. Las compañias por acciones (las citadas VOC y WIC) marcan, pues, la pauta en lugar del poder central. Es decir, la finalidad es primeramente el beneficio privado, y luego el público, aunque vayan mezclados, según constatan algunos autores de relieve ${ }^{51}$. Las Provincias Unidas constituyen una sociedad de aluvión, una sociedad regida por poderes económicos fuertes y muy compartimentados politica y geográficamente, pues en muchos aspectos dominan las provincias frente al difuso poder central. Una sociedad heterogénea donde va primando el derecho frente al privilegio. Una sociedad como la que necesita el capitalismo precisamente, aunque el sistema no naciera allí. Una sociedad general anónima contra una sociedad personal

50 ECHEVARRÍA BACIGALUPE, Miguel Ángel: En los origenes..., op. cit., pp. 205-206.

51 Véase al respecto, WESTSTEIJN, Arthur: Commercial republicanism in the Dutch Golden Age: The Political Thought of Johan \& Pieter de la Court, Leiden, 2012. 
limitada: son muy sugerentes los comentarios de Virgilio Malvezzi, comenzado el s. XVII, acerca de las diferencias entre régimen monárquico y republicano ${ }^{52}$. Sea cual fuere la definición del régimen económico neerlandés, es indudable que sus resultados ejercieron fascinación en Europa y aún en otros continentes dominados por los europeos: en 1700 su ingreso per cápita era un $50 \%$ superior al del Reino Unido, y "solo" el 40 \% de la fuerza de trabajo se empleaba en la agricultura (explotada con métodos modernos vinculados a un régimen económico capitalista), siendo por consiguiente una sociedad muy urbanizada en términos de la época53.

Desde el s. XVII, especialmente gracias a diversos movimientos políticos e intelectuales de acusada complejidad, en la cultura europea se van decantando las cosas hacia el mecanicismo (lo artificial, lo individual) frente al organicismo (lo natural, lo colectivo). Pero será una batalla dura, que solo se gana entrado el siglo XIX, y no en todas partes. El individualismo se afirma, y con él el egoísmo, es decir, la exaltación de la competencia, la rivalidad, el cálculo racional como instrumento. Con la Revolución Industrial y el liberalismo, el crecimiento se convirtió en desarrollo como objetivo a alcanzar.

\section{IV}

El siglo XVIII trajo a la vez la culminación y la crisis del sistema mercantil. Esta centuria conocerá de hecho un incremento del mercantilismo, pero a la vez el comienzo de su declive. Junto con esto, hay una característica que es preciso resaltar: el "sistema mercantil" del setecientos, si no más original, es más coherente que el de los siglos que le precedieron, sobre todo porque no hubo guerras tan extendidas, duraderas y destructivas como anteriormente. Además de esto, había nuevos problemas que épocas anteriores no conocieron, o lo hicieron con menor intensidad.

El mercantilismo como sistema se pensó y extendió, además de todo lo aludido precedentemente, para que las colonias se adaptaran de manera pasiva a las exigencias de la metrópoli, no elaborando aquello que pudiera concurrir con la "madre patria", y produciendo aquello que esta necesita, junto con una prohibición tajante de relacionarse con terceros. Es una división del trabajo pensada en beneficio exclusivo del centro rector, no de las necesidades de cada una de las partes. Pero la imposibilidad de abastecer la demanda de las colonias, propia de una economía preindustrial por sus limitaciones productivas, hará que las posesiones generen por sí mismas lo que solo en cantidades contadas les llega del centro, o que adquieran vía ilegal aquello que no pueden elaborar. Es la típica ineficiencia del sistema colonialista preindustrial que únicamente Inglaterra va a sortear con éxito relativo en el Siglo de las Luces,

52 Una ventaja tienen las repúblicas a los príncipes: aquellas son eternas y estos mortales. En ellas no mueren a un tiempo todos los que gobiernan, y queda siempre la mayor parte viva (MALVEZZI, Virgilio: Historia de Felipe III, Real Biblioteca de Madrid, ms. II/3075, f. ${ }^{\circ}$ 101). También, ECHEVARRÍA BACIGALUPE, Miguel Ángel: En los origenes..., op. cit., pp. 91-93. Sobre la preferencia holandesa por la república, VELEMA, Wyger R. E.: "That a Republic is better than a Monarchy: Anti-monarchism in Early Modern Dutch Political Thought", en Republicanism. A shared European Heritage, vol. I, Cambridge, 2002, pp. 9-25.

53 MADDISON, Angus, Las fases del desarrollo capitalista. Una historia económica cuantitativa, México, 1986, pp. 43-44. 
gracias a lo que llamaremos desde ahora "la introspección del mercado propio" (fig. 2). Llevarla a cabo, exigia dar una serie de pasos. Primero había que ordenar el propio mercado antes de saltar a otros. Pero para eso era necesario delimitar bien el espacio político y diseñar un programa de fomento, lo que solo se podía lograr en el tiempo largo.

¿Qué está pasando en la política económica de las potencias coloniales? Pues que según avanza el s. XVII, la dispersión espacial hacia el exterior, antes beneficiosa y aun obligada si se queria crecer, o cuanto menos subsistir, comienza a resultar una carga dificilmente soportable. Potenciar la periferia frente al centro, llevaba a poner a este en una situación cada vez más acusada de dependencia, conforme el espacio progresaba y se hacía más y más compleja su gestión. Para contrarrestar esta negativa tendencia, la prioridad debía ser revalorizar el papel de la metrópoli, y eso únicamente era viable si se llevaban a cabo políticas radicales de fomento interno. Esa conciencia será común a varias naciones instaladas en la lógica mercantil, bajo la cual los agentes económicos irán pasando de concebir un crecimiento centrífugo a otro donde la última palabra efectiva debería ser la metropolitana. Tal intención, asociada a la famosa "crisis de la conciencia europea" de que hablara Paul Hazard, encontrará grandes obstáculos, pues a las elites les convenía mantener en sustancia una situación que redundaba en su beneficio desde siglos atrás. Por eso, el propósito de unificar mercados, legislaciones e instituciones, obtuvo en el viejo continente un rechazo universal, si bien de diversa magnitud $^{54}$. Se diera antes o después, ese tránsito es un hecho de la mayor trascendencia histórica, sobre todo por haber generado profundas repercusiones en la posteridad. Veamos algunos casos destacables de ese esfuerzo por reforzar y modernizar el núcleo rector, lo que nos permite explicar las diferencias entre el viejo y el nuevo colonialismo. Las divergencias se sustanciarán aquí en dos modelos clave: el español y el británico. Atenderemos a alguna otra variable para tener más elementos de comparación, pero sin caer en una casuística farragosa que nos alejaría del fin que nos proponemos.

Figura 2. La introspección de los mercados

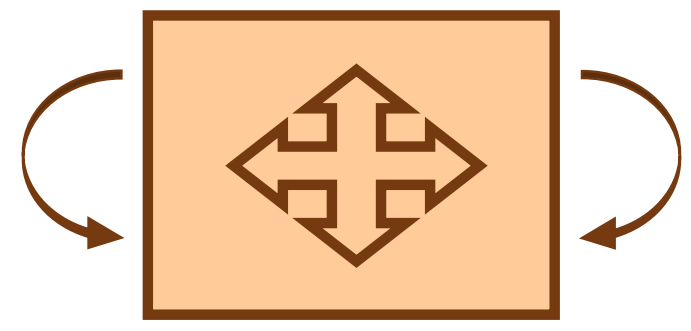

España es el ejemplo prototípico de viejo imperialismo, como volcado que estaba hacia fuera. La guerra de Sucesión la priva del control sobre territorios clave en Europa, y la orienta necesariamente hacia un eje atlántico con América (prolongado hasta Asia vía Filipinas) y otro hacia Italia, reforzando la "horizontalidad estratégica" de la politica exterior de la monarquía. España había dejado de ser hace años la potencia que dictaba normas y tratados, así que

54 ECHEVARRÍA BACIGALUPE, Miguel Ángel: "Sistema comercial e instituciones en los Países Bajos Modernos", Philostrato, n. ${ }^{\circ}$ extraordinario (2018), p. 246. 
hubo de conformarse con no salir perdedora neta en el juego internacional de alianzas e intereses. Si aún conserva cierta influencia en Italia, no es menos cierto, en nuestra opinión, que ceder los Países Bajos privaba a Madrid de un magnífico centro de observación y hasta de influencia en los asuntos europeos, a la vez que canalizaba hacia sí iniciativas y mejoras provenientes del dinámico espacio del Mar del Norte, con holandeses, ingleses y franceses como protagonistas. Seguramente las cosas sucedieron como debian haber sucedido, porque sin conexión terrestre o marítima consolidadas los españoles se veían incapaces de sustentar por sí mismos las posesiones septentrionales de la monarquía, y porque además nuestra presencia allí fue siempre bastante criticada entre la opinión pública. Pero el abandono de aquellas tierras flamencas, justo durante un proceso de creciente modernización en el área, no constituyó algo que pudiéramos calificar de beneficioso para nuestros intereses a plazo.

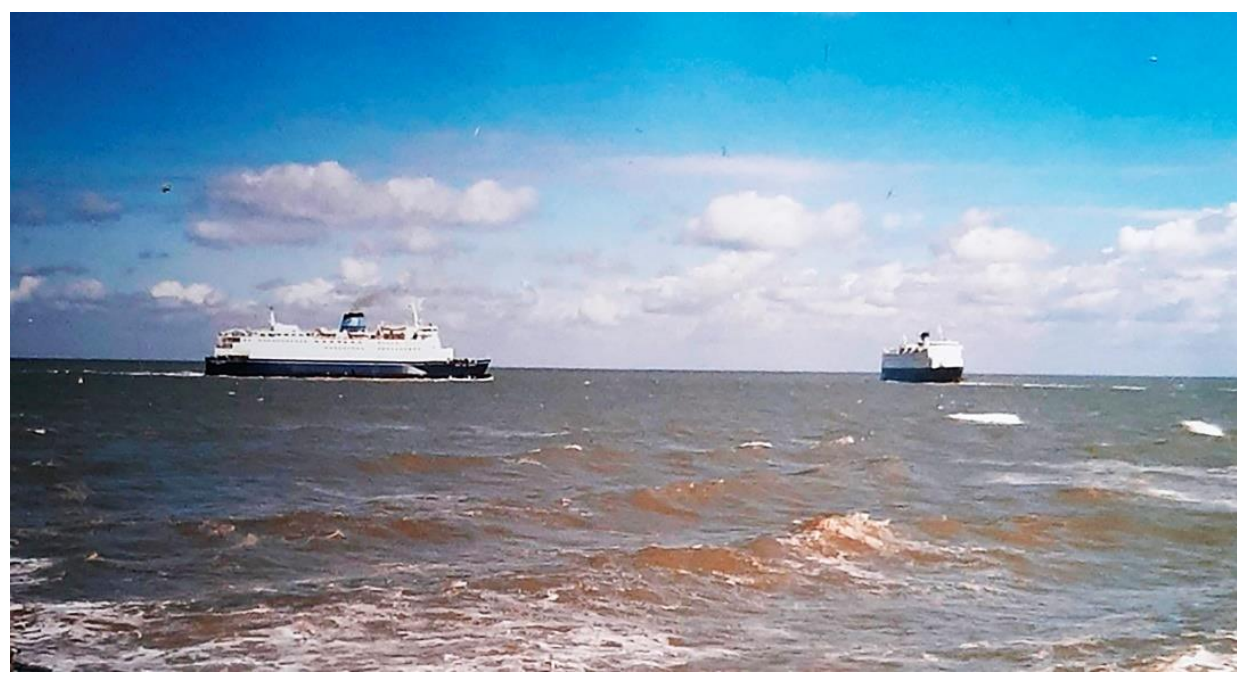

Imagen: Vista del Mar del Norte desde Ostende (Bélgica). El paso del tiempo no ha despojado a esta área maritima de su importancia e influjo. (Colección del autor)

La debilidad del núcleo rector resultaba tan clamorosa, que era preciso hacer algo para cuanto menos limitar su dependencia de terceros países o hasta de las posesiones propias. La tarea a efectuar era descomunal pero ineludible, y a ello se entregó la nueva dinastía en el poder. Los Borbones de España no variaron sustancialmente el programa económico de sus precedentes austriacos, e incluso pretendieron fortalecer todo lo posible el papel del Estado en la economía 55 . Consintieron al fin en liberalizar el mercado interior y dar un respiro al rígido mercado ultramarino, pero siguieron todo el tiempo en su tónica de proteccionismo exterior y de intervencionismo regulador ${ }^{56}$. A decir verdad,

55 LLOMBART ROSA, Vicent: "El pensamiento económico de la Ilustración en España", en FUENTES QUINTANA, E. (dir.): Economía y economistas españoles, vol. 3, Barcelona, 2000, p. 78. Para la politica económica y sus logros, ASTIGARRAGA, Jesús: Unifying Enlightment. Institutions of Political Economy in Eighteenth-Century Spain (1700-1808), Leiden, 2020.

56 Se intentó resucitar el derecho ad valorem sobre las mercancías perdido en 1648, siendo especialmente beligerante en ello Ustáriz (PLAZA PRIETO, Juan: Estructura económica de Es- 
hubo en aquel siglo ideólogos de relieve en materia económica, sobresaliendo Jerónimo de Ustáriz, Bernardo de Ulloa, Miguel de Zavala, el conde de Campomanes, Eugenio Larruga, Gaspar Melchor de Jovellanos, o el preliberal Valentín de Foronda. Encontramos asimismo notables representantes de la tendencia cameralista, una temática que abordara Ernest Lluch con su habitual brillantez; hay que destacar entre los lideres de aquel movimiento a Francisco Mariano Nipho, quien se encargó de que obras clave del cameralismo fueran traducidas de alemán al español ${ }^{57}$. Pero por mucho que busquemos, no hallaremos en todos ellos la originalidad y profundidad del pensamiento alcanzadas por la escuela salmantina siglo y medio atrás.

En el terreno práctico, resulta indudable el gran esfuerzo desplegado por los gobernantes para levantar a España del marasmo en que quedara tras dos siglos de incesante guerrear. De Felipe V a Carlos IV (aunque muy especialmente desde 1765) no faltaron iniciativas modernizadoras cuyas raíces se hallan a finales del s. XVII con el movimiento de los "novatores", culminando en las Sociedades de Amigos del País (partiendo del modelo vasco), más diversas instituciones científicas y de fomento. Todo ello evidencia un gran peso de las ideas europeas en España, que esta vez procede de tres frentes principales: el ya aludido cameralismo austríaco, el pensamiento ilustrado francés (a destacar en él la fisiocracia, con su tendencia liberalizadora de la que hicieron eco politicos y tratadistas desde el reinado de Carlos III) y, acabando la centuria, se hizo netamente visible el peso de las ideas y ejemplos ingleses. Seríamos injustos, con todo, si desdeñáramos el papel de la escuela de Salamanca en todo ello, aunque la realidad económica y política del setecientos era ya forzosamente distinta. El resultado fue aceptable considerando el punto desde el que se partía (ampliación del comercio colonial, fomento de las manufacturas, impulso del sistema bancario, extensión de la superficie agraria con nuevos métodos de cultivo...), pero se acumulaba un atraso secular, y la América hispana ya había iniciado su propia andadura social y económica; le faltaba únicamente desligar los lazos políticos con la metrópoli. Obrar en el sentido de seguir ampliando espacio (por ej., los notables avances hacia el norte del continente americano) complicó aún más las cosas, como se vería al poco; el modelo extensivo no iba a ser la solución. En ausencia de cambios profundos dentro de los sistemas productivo, de financiación y de distribución, y consideando el fuerte vínculo orgánico de la monarquía con sus posesiones extraeuropeas (que, recordémoslo, no eran colonias propiamente dichas), la ausencia de una política económica rupturista en el centro peninsular señalaba como inevitable el colapso del sistema, a pesar de los parches que se le aplicaron.

Acabaremos el caso hispánico aludiendo al peso del ejemplo inglés durante la última veintena del setecientos. Inglaterra era ya claramente la primera economía europea, no solo por su volumen, sino asimismo por la osada modernización del aparato productivo que estaba llevando a cabo. ¿Podría implantarse

paña en el siglo XVIII, Madrid, 1976, p. 857). Pero eso hubiera exigido de antemano un posicionamiento fuerte de España frente a terceras potencias que ya en el s. XVIII no estaba en condiciones de desplegar.

57 LLUCH MARTÍN, Ernest: "El cameralismo en España», en FUENTES QUINTANA, E. (dir.): Economía y economistas españoles, vol. 3, Barcelona, 2000, pp. 725-726. 
aquel modelo en el mundo hispánico? Si eso fuera posible, ¿bajo qué modalidades? Los españoles más perspicaces dirigieron su atención hacia aquel fulgurante astro para divulgar un modelo que no se disociaba del fisiócrata por el reclamo de la libertad de iniciativa, pero que irá bastante más allá de aquel. Liberalizar mercados fue calando con creciente intensidad en los ambientes económicos peninsulares. Lo paradójico es que esas ideas eran compartidas en el otro lado del Atlántico, pero con un objetivo bien distinto. La enriquecida sociedad criolla se desvinculó de la antigua metrópoli y buscó sus propios espacios amparada por el líder económico de entonces, que por supuesto era Gran Bretaña. Sin recursos para llevar a cabo una introspección eficiente, la España del s. XIX se verá obligada a encontrar su propia senda en medio de múltiples dificultades internas que retrasarán el proceso renovador; lo mismo pasaría con Portugal, otro clásico modelo extrovertido. Como la mudanza de sistema no podía lograrse en una o dos generaciones, se cambió una situación de dependencia ultramarina por otra, si bien respecto de países líderes en industrialización.

Los antiguos Países Bajos españoles fueron traspasados al emperador desde el Tratado de Utrecht. La atención de Viena hacia el territorio tras su anexión fue muy secundaria, pero la no injerencia de la corte vienesa, junto con un sólido pasado mercantil, financiero y transformador, permitió llevar a cabo una política autónoma de regeneración que daría espléndidos frutos llegada la mitad de siglo, y que no se detendría hasta las agitaciones de la Revolución francesa ${ }^{58}$. En cuanto a las vecinas Provincias Unidas, ya no eran capaces de afrontar ni la rivalidad francesa, ni sobre todo la inglesa. Instalados desde tiempo atrás en un sistema económico de alta elasticidad espacial, consiguieron hacer de Ámsterdam el principal mercado de capitales de la Europa ilustrada a costa de un retraso notable en los otros órdenes.

Las anteriores consideraciones nos abren paso al ejemplo de la Gran Bretaña. En concreto, Inglaterra conoció un éxito colonial indiscutible, solo empañado al no poder retener a las trece colonias de América del Norte, cuyo desarrollo era incompatible con las exigencias mercantilistas de Londres por similitudes en las respectivas estructuras económicas ${ }^{59}$. Pero una posible rebelión colonial mucho más extendida, a imitación de aquellas trece colonias, quedó frenada radicalmente. ¿Cómo fue posible que Gran Bretaña conservase su espacio mundial justo cuando otros lo estaban perdiendo?

Primero, porque los ingleses fueron capaces de transformarse a sí mismos antes de transformar a terceros. Y eso ocurrió de la manera siguiente: Inglaterra supo integrar antes su mercado interior que su expansión exterior, mediante una política que confia la gestión económica colonial al sector privado (compañias de comercio, particulares) ${ }^{60}$. Por cierto, que a los Países Bajos meridionales les pasó lo mismo décadas más tarde, en el ámbito de un mercado

58 ECHEVARRÍA BACIGALUPE, Miguel Ángel: "Sistema comercial...", art. cit., pp. 246-247.

59 Es cierto que tamaña pérdida se compensó en parte con el inicio de la colonización de Australia desde 1788, completando así la ocupación y explotación de la última gran superficie terrestre. La mundialización era, ahora sí, un hecho.

60 Las compañias de comercio actuaban de hecho como Estados fuera del Estado, tal y como ocurriera en Holanda. Eran, pues, una especie de Estados mercantilistas para el exterior. Los 
ya bastante interrelacionado ${ }^{61}$. Quede claro que no solo habia que integrar en lo económico, sino asimismo en lo político, porque sin esto último la tendencia hubiera sido estéril; es decir, el nuevo Estado liberal ha de imponer necesariamente la unidad de mercado. No es lo mismo la integración reticular espontánea en el Antiguo Régimen, que la marcada por una integración política deliberada, de raigambre mecánica y perimetral. El nuevo poder político hubo de coordinar el mercado de su propio territorio, pues de otro modo la integración estaría sometida a oscilaciones a veces contrarias al deseo unificador. Para eso hace falta que el espacio sea compacto, es decir, que se logre lo que desde ahora llamaremos NEM, o "nación-Estado-mercado", que se convertirá en la trinidad unitaria del régimen liberal (fig. 3). La revolución de 1688 abrió el camino para que varios decenios después se iniciara un complejo y espectacular proceso de modernización en el país ${ }^{62}$, en el que la teoría económica, bajo forma de escuela clásica (liderada por David Hume, Adam Smith y David Ricardo), proveerá de las herramientas ideológicas al nuevo sistema.

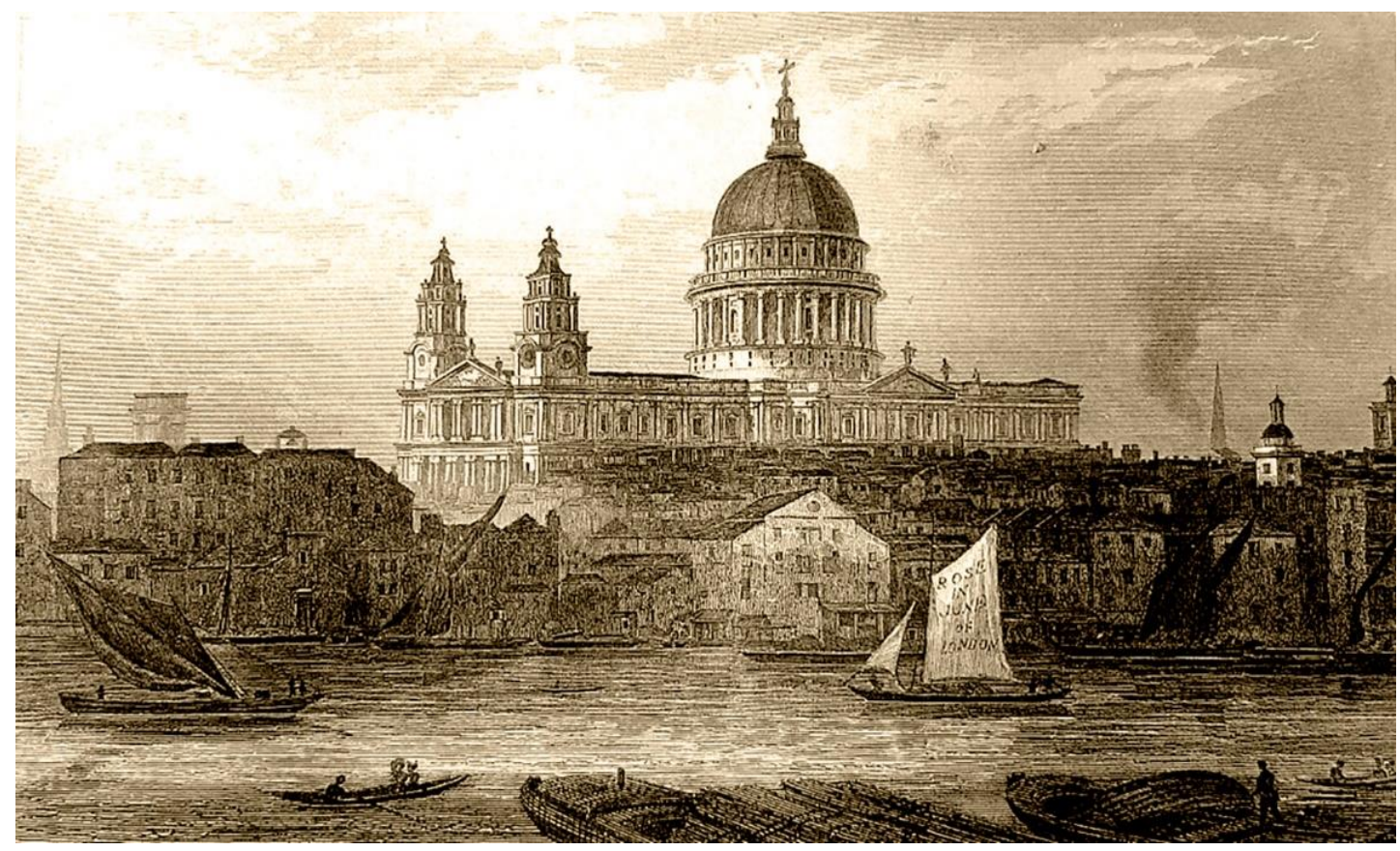

Imagen: Londres hacia 1820 [Grabado]. En esa época, Londres representa los nuevos aires de la economía-mundo, con la industrialización, el nuevo colonialismo y la filosofia del librecambio como enseñas. (Colección del autor)

particulares accedieron individualmente o asociados en compañias particulares desde el siglo XVIII, pero es preciso reconocer que lo hicieron con fuerza.

${ }^{61}$ BLONDÉ, Bruno: "Disparities in the development of the Brabantine Urban Network: Urban centrality, town-countryside relationships, and transportation development, 1750-1790", en Proceedings Twelfth International Economic History Congress, Madrid, 1998, p. 50. Asimismo, BUYST, Erik, Stefan DERCON y Björn VAN CAMPENHOUT "Market Integration in the Southern Low Countries in the second half of the XVIIIth Century", en NUNNEZ, C. E. (ed.): Integration of commodity markets in History, Madrid, 1998, pp. 31-41.

${ }^{62}$ Es referencia obligada el espléndido libro de PINCUS, Steve: 1688. La primera revolución mmoderna, Barcelona, 2013. Para nuestra finalidad, se hace recomendable consultar el capítulo XII sobre la revolución en el pensamiento económico. 
Figura 3. La NEM liberal

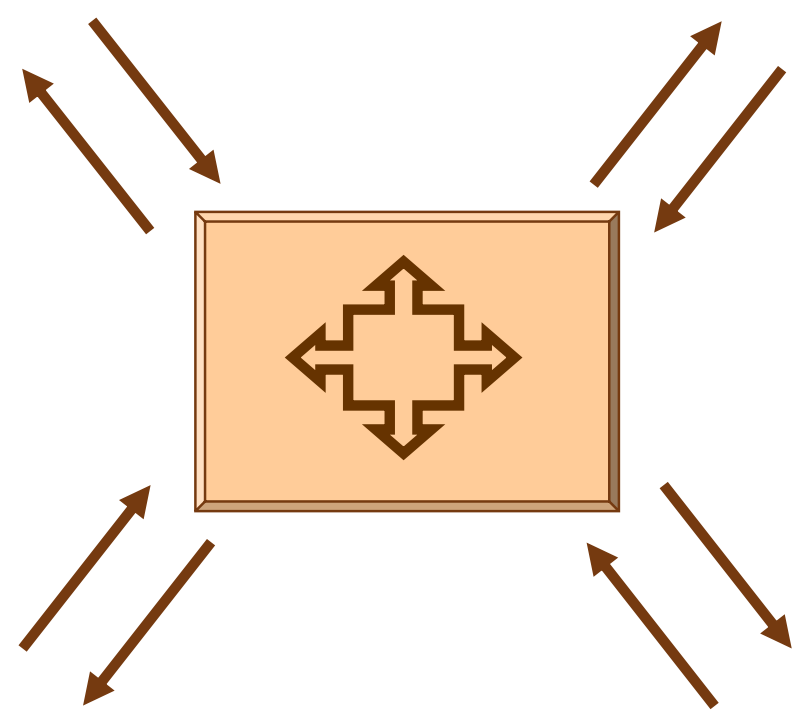

Pero a tales circunstancias, sin duda esenciales, se añadió otra de no menor calado, y que en cierto modo podría calificarse incluso de más honda. En efecto, si la reforma interna fue una condición absolutamente sine qua non, por si sola no podía bastar. Conseguir un mercado interior y haber revolucionado la estructura politica y empresarial desde finales del s. XVII era mucho, pero precisaba de otros requerimientos. A Inglaterra le ayudó el logro de su propia Revolución Industrial, sin la cual hubiera quedado, más allá de cualquier duda, a merced de las colonias (como les pasó, entre otros, a los ibéricos). Se trata, pues, de dos fenómenos concomitantes cuya separación haría inexplicable el proceso. Por otro lado, esa misma industrialización puso a Inglaterra por delante de los demás componentes del Reino Unido, permitiendo una unidad factual más que institucional. No estando limitada por el peso de su imperio, y hallándose muy por delante del resto de naciones, Gran Bretaña reforzará su influencia mundial entrado el siglo XIX, lanzándose a la ingente tarea de superar un reto que será distintivo de la era que acaba de nacer: la conquista del tiempo. Pero entonces ya no basará su expansión en el viejo mercantilismo de potestas regia, orillado en beneficio de una postura liberal en lo interno y librecambista en lo externo. Seguros de su competitividad, los británicos no necesitaban de barreras aduaneras ni leyes protectoras frente a terceros; será precisa una serie de cambios en profundidad, llegado el s. XX, para que Londres cambie de política.

Bélgica (parte sustancial de los antiguos Países Bajos meridionales), primera nación-Estado-mercado en seguir el ejemplo inglés, lo tuvo más fácil al no ser un imperio. Independiente desde 1830, y con un importante pasado manufacturero y financiero, para mediados del ochocientos será una economía de vanguardia, lo que le permitió una expansión colonialista en concordancia con los nuevos tiempos vinculados a la industrialización y el imperialismo. 
Un último modelo, para no extenderse más de lo debido. Francia representa una variable relativa de los precedentes casos, porque se ajusta en líneas generales a los principios y fines del mercantilismo ortodoxo, o como decimos aquí, extrovertido. A modo de preámbulo, decir que, superadas las guerras de religión del s. XVI, el nuevo Estado que salió de ellas tenderá a concentrar sus facultades en un centro politico: la Corte. No faltarán a la potestas regia quienes desde el plano teórico asienten una doctrina de economía diríamos "nacional" (nación = reino). Entre los más renombrados se encuentra Antoine de Montchrétien, autor de un tratado de gran difusión dentro y fuera del país ${ }^{63}$; además de impartir doctrina, Montchrétien, sin saberlo, dio nombre a la nueva ciencia económica que se estaba abriendo paso en aquel siglo. El autor francés piensa en términos territoriales muy precisos, los del Estado-reino, y se aleja de cualquier consideración astronómica o de influencia del macrocosmos (el universo) sobre el microcosmos (el ser humano). Se trata aquí de intereses terrenales vinculados entre el rey y sus vasallos sustentadores.

Hay un paso, pues, de la espacialidad cósmica a la espacialidad geográfica, al identificar nación con rey y con sistema monárquico (esto es, el espacio institucional). La economía está al servicio de la política, y no al revés; eso ya quedó claro desde Jean Bodin, en el siglo XVI. De hecho, en Francia la economía política deviene política económica, es decir, predominio de lo público sobre lo privado. El Estado debe controlar ese miedo a la volatilidad espacial de que hemos hablado anteriormente; de ahí la estanqueidad proteccionista promovida por Montchrétien, a base de relaciones controladas desde el centro politico64.

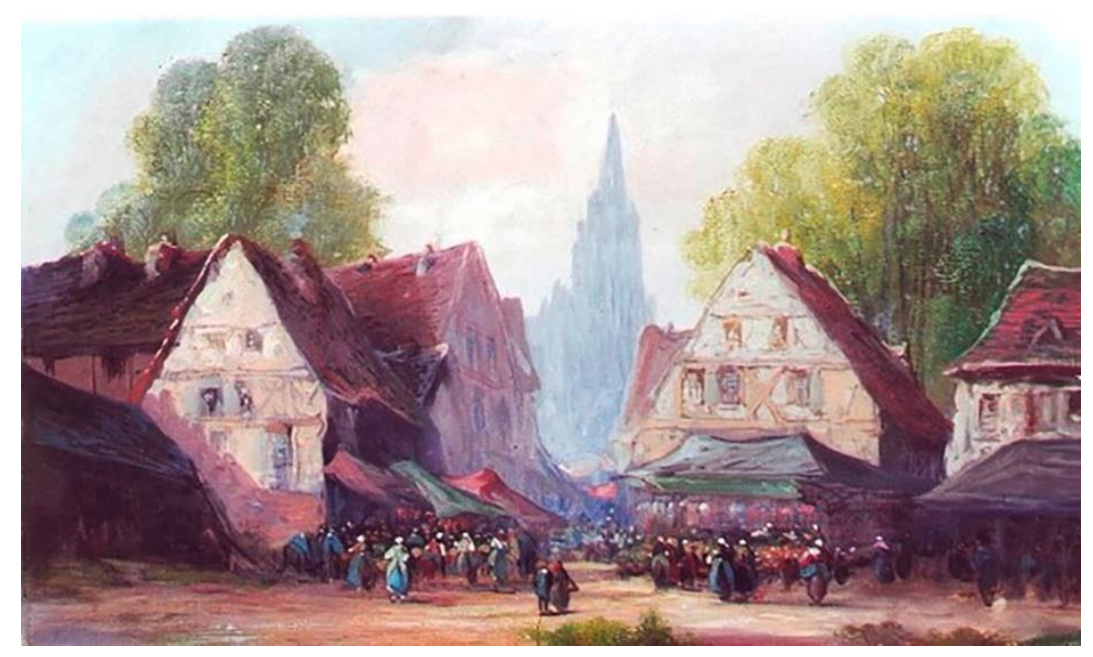

Imagen: P. Devillers: Mercado de Rouen [óleo]. Unir la macro y la microeconomía fue la obsesión de memorialistas y políticos franceses desde el siglo XVI. (Colección del autor)

La expansión francesa acabó siendo amplia en el sentido geográfico, pero no tan profunda como en otros ejemplos atrás valorados, rodeada como se hallaba Francia por enemigos deseosos de limitar su poder; reforzar lo interno era tarea prioritaria. Añadamos a tal circunstancia el malísimo recuerdo que

63 MONTChRÉtien, Antoine de: Traité de l'Economie Politique, (M. Laudet, Ed.), Paris, 2017.

64 Ibid., pp. 208-209. 
dejó, a comienzos del s. XVIII, el llamado "sistema Law", una aventura especulativa entre el arbitrismo monetario y la expansión colonial, cuyo fracaso marcaría profundamente el devenir económico del setecientos francés, alejado, sí, de especulaciones, pero también de innovaciones económicas ${ }^{65}$. La alternativa solo podía pasar -otra vez- por potenciar el núcleo interno, la metrópoli. Tocada muy seriamente la expansión ultramarina, las generaciones educadas en la doctrina de Montchrétien y las prácticas de Jean-Baptiste Colbert buscarán en tierra lo que no encontraban en el mar. El imperialismo francés se vuelve territorial, alejándose de ambiciones oceánicas y centrándose en el desarrollo interno para pasar luego a la conquista del continente europeo a partir de la misma Francia. Tal es el sentido de la expansión napoleónica, más cercana a la china o a la rusa, de carácter geocrático, que a la de sus vecinos de Europa occidental, con talasocracias tan típicas como la holandesa y la inglesa. El fracaso de esta nueva aventura marca el fin de la que se denomina segunda guerra de los Cien Años (1688-1815), en que Francia pierde su pulso con la Gran Bretaña por el dominio colonial y posteriormente global. La aventura africana, llegado el s. XIX, reabrirá la opción francesa por el modelo disperso, tratando de recuperar poder e influencia en nuevos espacios a conquistar. Aunque sin perder de vista el desarrollo interno en una época de creciente nacionalismo, la expansión exterior francesa tuvo un indudable rasgo de modelo colonial de antiguo orden.

Señalaremos, además, el empuje de doctrinas contrarias a la mercantilista por obra de gentes cercanas a la Enciclopedia, comenzando por la escuela fisiocrática. Libertad de mercado y libertad de iniciativa fueron sus divisas. El impacto de la Revolución de 1789 avivó la corriente liberalizadora, pero tras el vendaval transformador, el país solo conseguirá ofrecer al mundo una llamativa dualidad: la de un gobierno inspirado en el mercado único como base, que choca de frente con la vanguardia de la teoría económica, cuyos ideales se acercaban al liberalismo de raigambre inglesa ${ }^{66}$. La victoria, finalmente, caerá del lado de la tradición, que ahora se acomodaba perfectamente al trinomio NEM, tan en boga.

\section{V}

Es hora de concluir nuestro relato. En todos los casos que hemos presentado aquí, ya desde el siglo XVI, pero en especial desde el Siglo de las Luces, se evidencia el inicio de un fenómeno histórico que se caracteriza por la expansión a partir de un centro cada vez más unificado y moderno, el cual halla en el ensanchamiento de los mercados el método más idóneo para seguir creciendo, y que se ve obligado a reinventarse para mantener su hegemonía. La idea germinal de los mercantilistas, identificando potestas regia y mercado exterior, se traslada con el tiempo hacia la idea de nación soberana desarrolla-

$65 \mathrm{El}$ sistema Law tenía aspectos positivos e innovadores, pero la quiebra del experimento desprestigió al conjunto. Ha tenido amplio seguimiento historiográfico. Por citar alguna obra relevante, MURPHY Antoin E.: John Law. Economic Theorist and Policymaker, Oxford, Clarendon Press, 1997. Los memoriales de Law exponiendo a la regencia su plan, en DAIRE, Eugène: Economistes financiers du XVIII siècle, Genève, 1971, pp. 443-655.

${ }^{66}$ Curiosamente, el liberalismo teórico francés resultó de los más osados de aquel tiempo, dando nombres tan conocidos a la historia del pensamiento económico como Jean-Baptiste Say o Frédéric Bastiat. 
llada, y luego a la de dispersión global, gracias al imperialismo colonialista. Fue, en líneas generales, un camino expansivo-contractivo típico del movimiento espacial a plazo; por consiguiente, algo tan inevitable como previsible.

Creo haber dejado claro aquí que el crecimiento espacial es una constante en la economía de Antiguo Régimen y en la contemporánea. Pero resulta que la moderna teoría económica apoya esta interpretación. Las estadísticas de Maddison, y especialmente las de Jorgenson, junto a sus respectivos modelos econométricos, muestran muy a las claras que el factor clave de toda expansión económica no es tanto la productividad de los factores como más bien su acumulación en el espacio, vía transformaciones estructurales internas y comercio exterior 67 . Crecimiento del producto y difusión espacial vienen a ser lo mismo según estos autores, lo que (entre otras cosas) anula la opinión aún muy extendida de que el colonialismo de los siglos modernos fue ruinoso para las naciones europeas, o en el mejor de los casos, indiferente 68 . Opinamos, por nuestra parte, que lo problemático se da realmente cuando, vinculadas metrópoli y colonias, la misma dispersión acaba por perjudicar al elemento metropolitano, hasta entonces beneficiado, complicando su crecimiento. Se trata de un proceso basado en el límite de la eficiencia espacial por el que todas las grandes economías han de pasar antes o después, con más o menos éxito. Es una de esas lógicas inexorables de la historia (por cierto, también visible en nuestros días).

¿Desapareció el mercantilismo con el nuevo régimen político? Si nos atenemos a los principios del sistema, responderemos que sí. La teoría y la práctica económicas se irán sofisticando respecto de los tiempos modernos, qué duda cabe. Pero el nacionalismo y el imperialismo colonialista del s. XIX resucitan el espíritu del viejo sistema mercantil. El concepto de nación-Estado-mercado, inicialmente mecánico, llevará a cada entidad a constituirse en un órgano compacto en sí mismo, un organismo que entrará en competencia con otros de su entorno. El NEM, con sus fronteras claramente definidas tras las cuales se busca la homogeneización interior apoyada por el vertiginoso desarrollo económico industrial y de un espacio propio, solo podia degenerar en un nuevo organicismo supremacista hostil a su entorno. La I Guerra Mundial y los horrores del siglo xx estaban servidos.

67 MADDISON, Angus: Historia del desarrollo capitalista, sus fuerzas dinámicas: una visión a largo plazo, Barcelona, Ariel, 1991; igualmente, JORGERSON, Dale W.: The Economics of Productivity, London, E. Elgar, 2009.

68 O'BRIEN, Patrick K., y Leandro PRADOS DE LA ESCOSURA: "Prefacio", Revista de Historia Económica, XVI, 1 (1998), pp. 9-10. 